\title{
Alkylation of Benzene with Technical Fraction Propylene - Propane Over Modified B-(Al)-HZSM-5 Catalysts
}

\author{
IULIEAN VASILE ASAFTEI ${ }^{1}$, MARIA IGNAT ${ }^{1 *}$, CATALIN NECULAI LUNGU ${ }^{1}$, ION SANDU ${ }^{2,3 *}$, ELVIRA MAHU ${ }^{1,3}$ \\ ${ }^{1}$ Alexandru I. Cuza University of Iasi, Faculty of Chemistry, Laboratory of Materials Chemistry, 11 Carol I Blvd, 700506, Iasi, \\ Romania \\ ${ }^{2}$ Alexandru I. Cuza University of Iasi, ARHEOINVEST Interdisciplinary Platform, 22 Carol I Blvd, 700506, Iasi, Romania \\ ${ }^{3}$ Romanian Inventors Forum, 3 Sf. Petru Movila, BI. L11, Sc. A, Et. III, Ap. 3, 700089, Iasi, Romania \\ ${ }^{4}$ Petru Poni Institute of Macromolecular Chemistry, Laboratory of Inorganic Polymers, 41A Grigore Ghica Voda Alley, 700487, Iasi, \\ Romania
}

\begin{abstract}
Benzene alkylation with propylene - propane technical mixture over B-(Al)-HZSM-5 zeolite, as solid acid catalyst has been studied. It was found that izopropylbenzene (IPB) formation associate with a low level of byproducts, e.g., n-propylbenzene (NPB) and di-izopropylbenzenes (DIPB) as result of the inherent multiple competing reactions. Under the specific conditions in the alkylation of benzene with propylene -propane mixture, the maxim yields of IPB (\% wt.) and the IPB selectivity based on benzene reaction (wt.\%) were 86, 87 and $87.0 \%$.
\end{abstract}

Keywords: alkylation, benzene, izopropylbenzene, B-(Al)-HZSM-5

In the last decades, the pentasil - type zeolites, containing $\mathrm{B}, \mathrm{Ga}, \mathrm{Zn}, \mathrm{Fe}, \mathrm{Ti}$, etc., were found very active catalysts in many reactions: aromatization, alkylation, oxidation, etc. Ga-HZSM-5 and /or pentasil-type gallosilicates, and ZnHZSM-5 proved to be very active catalysts for the aromatization of light hydrocarbons (alkanes and alkenes) [1-33].

The MFI-titanosilicates are industrial catalyst for the oxidation of alkenes or aromatics hydrocarbons with hydrogen peroxide as oxidant [34].

B-HZSM-5 and borosilicates MFI-type are preferred in selective production of $p$-disubstitute dialkylbenzenes by alkylation, isomerization and disproportionation reactions $[35,36]$. The Fe-MFI zeolites found their best application in the selective alkylation [37, 38].

The conventional catalysts for benzene alkylation with alkenes $\left(\mathrm{C}_{2}=\mathrm{C}_{3}=\right)$ are supported phosphoric acid in a fixed bed reactor with reactants in liquid phase (UOP) or FriedelCrafts $\mathrm{AlCl}_{3}$ (Monsanto). Environment protection, process safety and avoidance of corrosion request for replacing these catalysts by regenerable solid acids.

Benzene and toluene alkylation with olefins was effected on $Y$ or $X$ zeolite and mordenite [39-42].These catalysts present good activities but short time of reaction because of catalysts deactivation by coking. The application of a Y type zeolite operating in the liquid phase, alkylation of benzene with ethylene was industrially performed and commercialized since 1989 by Lummus/ Unocal/UOP [43]. The MFI zeolite is a very good catalyst for benzene alkylation (Mobil- Badger) in commercial use since 1976, and toluene alkylation with ethylene operating in gas phase [44-46]. Benzene alkylation with propylene in liquid phase was studied on, mordenite, MCM-22, ZSM5, USY, ZSM-12 and zeolite $\beta$ [47-59].

In this work we are presenting our results on alkylation of benzene with $\mathrm{C}_{3}=/ \mathrm{C}_{3}$ technical fraction on the $\mathrm{B}-\mathrm{HZSM}-5$ catalyst.

\section{Experimental part \\ Synthesis of NaZSM-5}

The NaZSM- 5 zeolite was synthesized by hydrothermal crystallization at $180 \pm 5^{\circ} \mathrm{C}$ for $24 \mathrm{~h}$ under autogenously pressure from a mixture containing sodium silicate, aluminum sulphate, ethylene glycol (EG), sulphuric acid, ammonia solution and distilled water. The procedure of synthesizing NaZSM-5 in our laboratory from the amorphous hydrogel with molar ratio $\mathrm{SiO}_{2} / \mathrm{Al}_{2} \mathrm{O}_{3}=58.92$, $\mathrm{HO}$ available $/ \mathrm{SiO}_{2}=0.22, \mathrm{Na}^{+}$total $/ \mathrm{SiO}_{2}=0.72, \mathrm{EG} / \mathrm{SiO}_{2}$ $=0.40$ and $\mathrm{H}_{2} \mathrm{O} / \mathrm{SiO}_{2}=31.10$ and $\mathrm{pH}=11.50$ is based on method described in [60]. The first synthesis of ZSM-5 zeolite using tetrapropylammonium bromide as template belongs to Argauer and Landolt [61].The crystalline product was filtered, washed with distilled water, dried at $110^{\circ} \mathrm{C}$ for 6 hours and calcined at $550^{\circ} \mathrm{C}$ for $6 \mathrm{~h}$ to remove the organic material and to obtain sodium form, Na-ZSM-5.

\section{Zeolite modification}

The sodium form of the Na-ZSM-5 $\left(\mathrm{SiO}_{2} / \mathrm{Al}_{2} \mathrm{O}_{3}=34.65\right)$ was converted into the $\mathrm{NH}_{4}{ }^{+}$form by ion exchange (three consecutive times) with a solution of $1 \mathrm{M} \mathrm{NH} \mathrm{NO}_{3}$ (ratio solid: liquid $=1: 5$ ) at $80^{\circ} \mathrm{C}$ for $6 \mathrm{~h}$ under mild stirring. The solid was then filtered, washed, dried over night at $110^{\circ} \mathrm{C}$ and calcined in air at $550^{\circ} \mathrm{C}$ for $6 \mathrm{~h}$ when the protonic form HZSM-5 with acid properties was obtained.

By treating HZSM-5 sample with $1 \mathrm{M}$ solution of $\mathrm{H}_{3} \mathrm{BO}_{3}$ $\left(0.09 \mathrm{~g} / \mathrm{g} \mathrm{B}_{2} \mathrm{O}_{3} / \mathrm{HZSM}-5\right)$ at $80^{\circ} \mathrm{C}$ for $10 \mathrm{~h}$ a nonskeletal boroncontaining catalyst was prepared. The suspension was dried over night at $110^{\circ} \mathrm{C}$ and calcined at $400^{\circ} \mathrm{C}$ for $6 \mathrm{~h}$ when nonskeletal and skeletal boron catalyst was prepared. The solid encoded B-(Al)-HZSM-5 contain 8.26 $w t \%$ as $\mathrm{B}_{2} \mathrm{O}_{3}$ (2.56 wt $\%$ B).

The final catalyst was prepared by mechanically mixing the B-(Al)-HZSM- 5 powders with $20 \mathrm{wt} \% \gamma-\mathrm{Al}_{2} \mathrm{O}_{3}$ as binder and a little distilled water until a soft paste was obtained and extruded into pellets. The pellets were dried at $110^{\circ} \mathrm{C}$ overnight and activated in $\mathrm{N}_{2}$ at $450^{\circ} \mathrm{C}$ for $6 \mathrm{~h}$.

\section{Physico-chemical characterization}

X-ray pow der diffraction (XRD) patterns were acquired on a PANalyticalX'PertPRO MPD diffractometer using CuK radiation ( $1.5406 \AA), 40 \mathrm{kV}, 30 \mathrm{~mA}$ in the $5^{\circ} \leq 2 \theta \leq 31^{\circ}$ angular region, with $0.0131^{\circ}(2 \theta)$ step size. Nitrogen adsorption-desorption isotherms at $77 \mathrm{~K}$ were obtained with a Sorptomatic Carlo - Erba Series 1800 apparatus. Surface

\footnotetext{
*email: maria.ignat@uaic.ro; sandu_i03@yahoo.com
} 
areas were calculated with BET equation. Scanning electron micrograph (SEM) and elemental analysis (EDX) were collected on a VEGA II LSH (TESCAN) with EDX detector tip Quantax QX2 (Bruker).

The acidity and strength distribution of $\mathrm{H}-\mathrm{ZSM}-5$ and $\mathrm{B}$ (AI)-HZSM-5 were evaluated by using temperature programmed desorption (TPD) of ammonia technique. The samples were activated in a flow of dry $\mathrm{N}_{2}$ at $500^{\circ} \mathrm{C}$ for $4 \mathrm{~h}$ and after cooling to $80^{\circ} \mathrm{C}$ ammonia adsorption take places. Physically adsorbed ammonia was removed by degassing in flowing $\mathrm{N}_{2}$ at $100^{\circ} \mathrm{C}$ for $3 \mathrm{~h}$. The amount of ammonia desorbed from 100 to $800^{\circ} \mathrm{C}$ (at the rate of $10^{\circ} \mathrm{C} / \mathrm{min}$ ) was quantitatively monitored volumetrically (absorption in $1 \mathrm{M}$ $\mathrm{HCl}$ ). The total ammonia desorbed corresponds to number of acid sites and the desorption temperature to the strength of acid sites (weak and strong). Si and Al contents were determined using the ordinary wet chemical methods and the content of Na was measured flamphotometrically at $589 \mathrm{~nm}$.

\section{Catalytic tests}

Performances of the B-Al-HZSM- 5 catalyst for benzene alkylation with $\mathrm{C}_{3}=/ \mathrm{C}_{3}$ technical fraction were established in temperature at $250^{\circ} \mathrm{C}$, under $40 \mathrm{~atm}$. pressure, $\mathrm{WHSV}=$ 2,35 $\mathrm{h}^{-1}$ and benzene : propylene molar ratio of 7:1, in a fixed bed continuous flow stainless-steel reactor (Twin Reactor System Naky, Metrimpex). The operating conditions (temperature, WHSV, pressure and benzene: propylene molar ratio) were in advance selected to obtain the high yield of IPB during the catalytic tests. Control of temperature, pressure, as well as gaseous feed was done through automatic devices. The reaction products were separated into gaseous and liquid fractions through an icetrap. The gases resulted from catalytic test were analyzed using a Carlo Erba G.C. (Model C, TCD) equipped with a 6 $\mathrm{m}$ column filled with squalane and dimethylsulfolane on Chromosorb P. The collected liquid corresponding to each catalytic test was analyzed with a Carlo Erba Vega G.C. (FID) equipped with a $25 \mathrm{~m}$ capillary column filled with SE-52 stationary phase.

\section{Results and discussions \\ Structure, morphology and specific surface area}

Figure 1 shows the XRD patterns of parent NaZSM- 5 sample after calcinations and of B-HZSM-5 composite after the heat treatment. The pattern confirms that the synthesized zeolite has the structure identical to MFI-type zeolite [62]. The parent NaZSM-5 has a high crystallinity derived from the high intensities of the XRD reflections in the range of $22.5-25^{\circ}(2 \theta)$. No other diffraction lines were found in the XRD pattern. The XRD pattern of $\mathrm{B}(\mathrm{Al})$-HZSM5 composite obtained at $400^{\circ} \mathrm{C}$ shows that the structure of host ZSM- 5 was retained and in addition exhibit reflection at 14.61 and $28.10(2 \theta)$ which are characteristic for the $\mathrm{B}_{2} \mathrm{O}_{3}$ crystalline particles that cover the external and internal surface of HZSM-5 zeolite. The intensities of these peaks

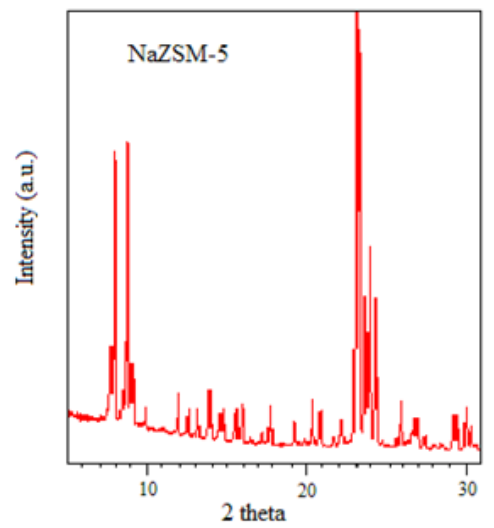

NaZSM-5

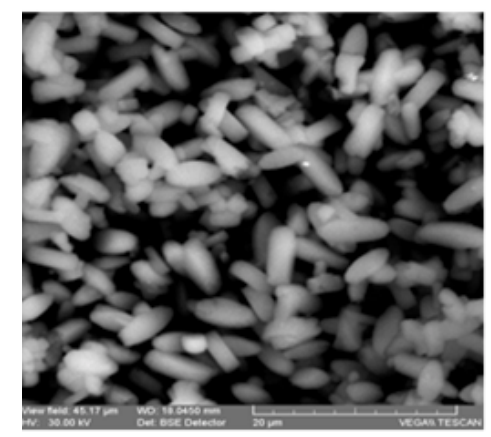

HZSM-5

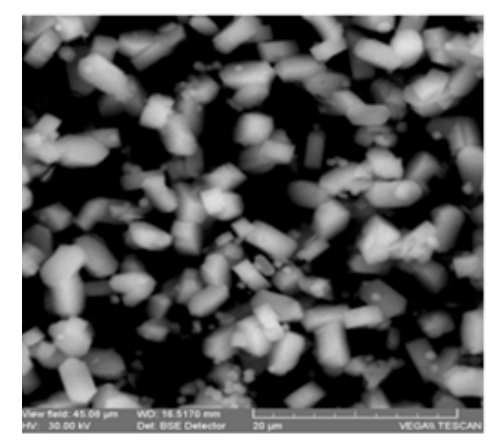

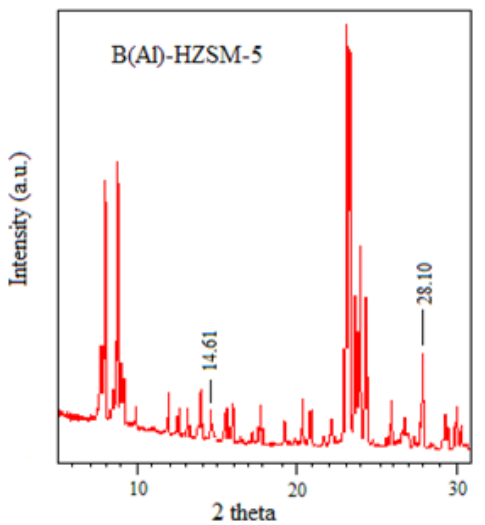
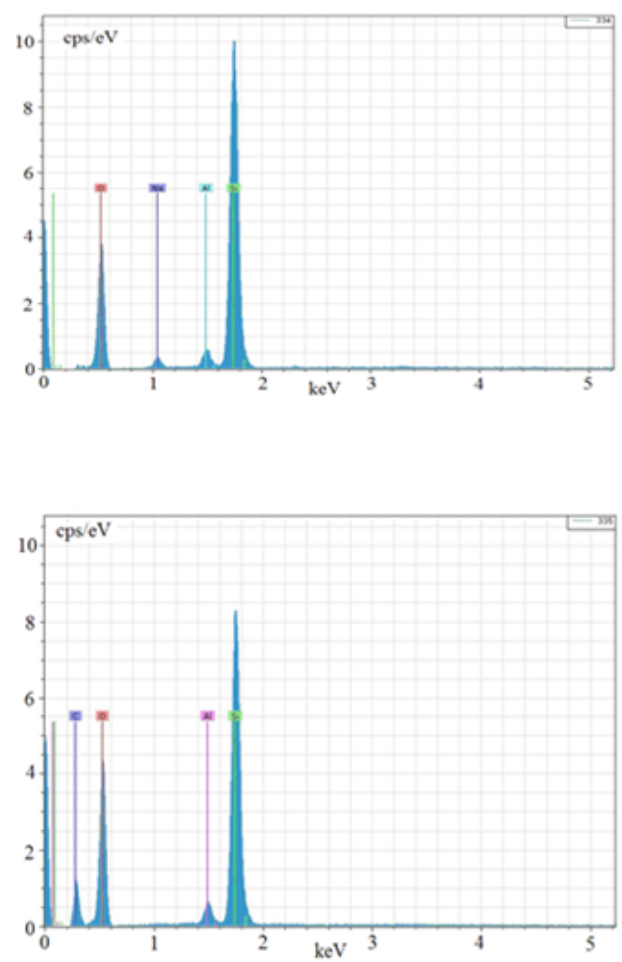

http://www.revistadechimie.ro
Fig.1. XRD powder patterns of calcined parent NaZSM-5 and of B-(Al)-HZSM-5 composite after the heat treatment at $400^{\circ} \mathrm{C}$ [63]
Fig. 2. SEM images of parent NaZSM-5 and HZSM-5 zeolites and their EDX spectra [63] 
decreased until disappearance during the thermal activation at $400^{\circ} \mathrm{C}$ for $6 \mathrm{~h}$ and after the catalytic tests indicating a host-guest interaction and an isomorphic substitution of tetrahedral aluminium with tetrahedral boron.

After $6 \mathrm{~h}$ of calcinations at $400^{\circ} \mathrm{C}$ no more $\mathrm{B}_{2} \mathrm{O}_{3}$ crystals exist in the B-(Al)-HZSM-5 samples. This change might be interpreted by the dispersion of $\mathrm{B}_{2} \mathrm{O}_{3}$ as a monolayer into the channels of HZSM-5 matrix. [64-66]

Figure 2 presents the SEM images of parent NaZSM- 5 and of HZSM-5 and the elemental composition by EDX spectra. It reveals the well-defined morphology of crystals indicating highly crystalline material. The EDX spectrum of HZSM-5 zeolite proves the absence of $\mathrm{Na}^{+}$ions after the ammonium exchange of NaZSM-5 zeolite.

The chemical oxidic composition of the calcined NaZSM-5 sample corresponds to values: $92.70 \mathrm{wt} \% \mathrm{SiO}_{2}$ $4.54 \mathrm{wt} \% \mathrm{Al}_{2} \mathrm{O}_{3}$ and $2.76 \mathrm{wt} \% \mathrm{Na}_{2} \mathrm{O} ; \mathrm{SiO}_{2} / \mathrm{Al}_{2} \mathrm{O}_{3}=34.65$; $\mathrm{Na}_{2} \mathrm{O} / \mathrm{Al}_{2} \mathrm{O}_{2} \stackrel{2}{=} 1.001$.

The BET surface area of NaZSM-5, HZSM-5 and B-(Al)HZSM-5 samples were $316.2 \mathrm{~m}^{2} / \mathrm{g}, 296 \mathrm{~m}^{2} / \mathrm{g}$ and $286 \mathrm{~m}^{2} / \mathrm{g}$ respectively. The boric acid impregnation of HZSM-5 zeolite may narrows the pore openings and plugs the channels, so the specific surface area is decreased.

Acidity of HZSM-5 and -B(Al)-HZSM-5 catalysts

The acid properties of the catalysts determined by means of ammonia temperature programmed desorption (TPD) measurements are presented in table 1.

\section{Table 1}

TOTAL ACID SITES AND ACID STRENGTH DISTRIBUTION

\begin{tabular}{|l|l|c|c|}
\hline Catalyst & $\begin{array}{l}\text { Total ammonia } \\
\text { chemisorbed }\end{array}$ & Acid strength, mmol NH$/ \mathrm{g}$ \\
& $\begin{array}{l}\mathrm{LT} \\
\mathrm{mmol} / \mathrm{g}\end{array}$ & $120-300^{\circ} \mathrm{C}$ & $300-600^{\circ} \mathrm{C}$ \\
\hline HZSM-5 & 0.916 & 0.618 & 0.298 \\
\hline B(Al)-HZSM-5 & 0.893 & 0.795 & 0.098 \\
\hline
\end{tabular}

HZSM-5 modified by impregnation with boric acid and pre-treated at high temperature $\left(400^{\circ} \mathrm{C}\right)(\mathrm{B}(\mathrm{Al})$ - HZSM-5 catalyst) contain nonskeletal boron $\left(\mathrm{B}_{2} \mathrm{O}_{3}\right)$ and skeletal tetrahedral and trigonal boron ( $\equiv \mathrm{Si}-\mathrm{O}(\mathrm{H}) \mathrm{Ba} \equiv)$ as a result of partially dealumination of ZSM-5 matrix. The hydroxyl groups associated with skeletal $\mathrm{B}^{3+}$ led to weak Bronsted acid sites and in consequence different catalytic properties in comparison with the parent HZSM-5 catalyst [53-57].

Performance of $B-(A I)-H Z S M-5$ catalyst in benzene alkylation with $C_{3}=/ C_{3}$ technical fraction

Six catalytic of approximately $48 \mathrm{~h}$ working tests with regeneration after each one were performed on $\mathrm{B}$-(Al)HZSM- 5 at $250^{\circ} \mathrm{C}$, under $40 \mathrm{~atm}$. pressure, WHSV $=2.35$ $h^{-1}$ and benzene: propylene molar ratio of $7: 1$. Variation of the propylene concentration and the corresponding liquid product after each 3 working hours during a $54 \mathrm{~h}$ test is present in figure 3 and 4 . During the $36 \mathrm{~h}$ the propylene are consume completed after he concentration in reaction gases increased off because the catalyst inactivation by progressive cocking. Among propylbenzenes compounds, cumene (IPB) is the main product, representing approx. 84 wt. \% in this.

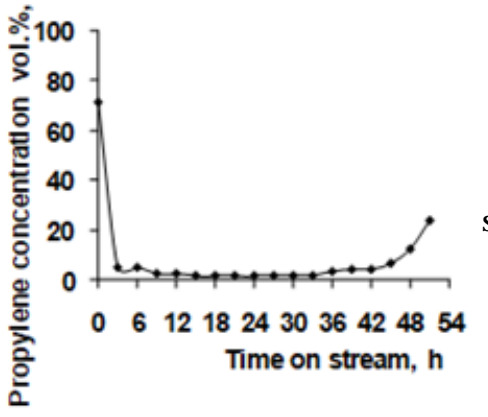

Fig.3. Variation of the propylene concentration in reaction gases vs. time on stream in benzene alkylation with technical fraction $\mathrm{C}^{3=} / \mathrm{C}$ at $250^{\circ} \mathrm{C}$ and $40 \mathrm{~atm}$

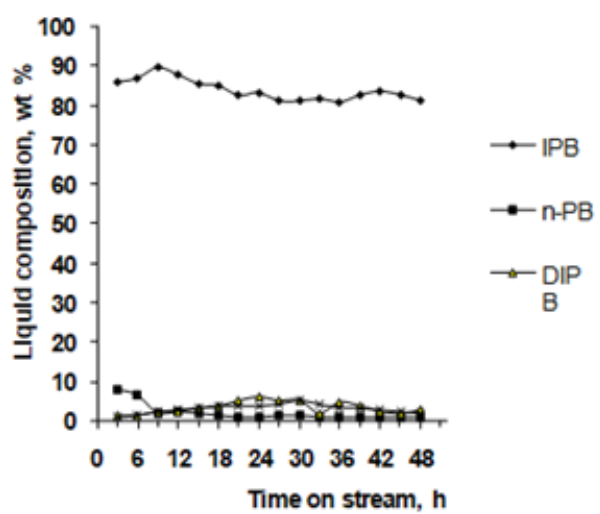

Fig.4. Variation of the propylbenzenes concentration vs. time on stream in benzene alkylation with technical fraction $\mathrm{C}^{3}=/ \mathrm{C}_{3}$ at $250^{\circ} \mathrm{C}$ and $40 \mathrm{~atm}$

n-Propylbenzene, an undesirable by-product is obtained in a small quantity, he concentration in liquid product exceed of $2.0 \mathrm{wt} \%$ only in firstly hours, and diisopropylbenzenes (1,3 and 1,4-DIPB) is obtained very probably by direct cumene alkylation with propylene and his concentration is up $2.0 \mathrm{wt} \%$ in liquid product. Propylbenzenes distribution and IPB, and DIPB selectivity (middle values per test) over the six catalytic working tests of benzene alkylation with $C_{3} / C_{3}=$ technical fraction over $B$ (AI)-HZSM- 5 are presented in table 2 and figure 5.

IPB selectivity vs. of benzene consumed is up 83 wt. \% and IPB selectivity vs. of propylene is up $76 \mathrm{wt} \%$. The IPB conct

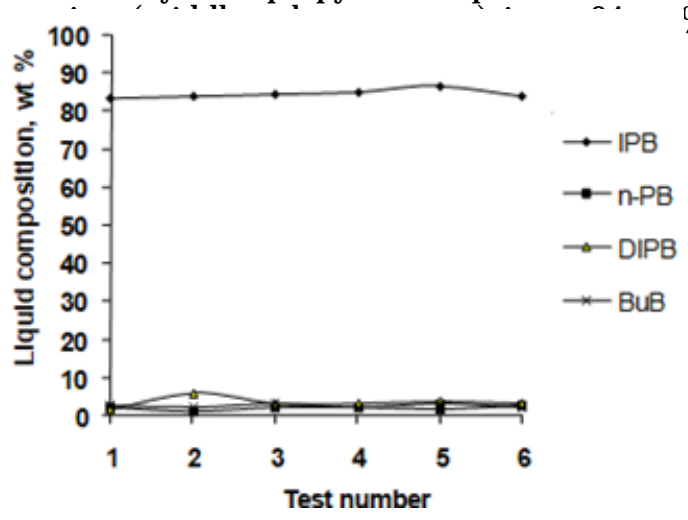

Fig. 5. Variation of liquid components concentration over six catalytic working tests of benzene alkylation with $\mathrm{C}_{3}=/ \mathrm{C}_{3}$ technical fraction over B-(Al)-HZSM-5 liquid products, the $n-P B$ concentration not exceed of 2.5 wt.\% and the DIPB concentration increased at $1.910 \mathrm{wt} . \%$ in the first test at $6.28 \mathrm{wt} \%$ (fig. 5).

Propylbenzenes (PB) selectivity was calculated as:

The reaction scheme for benzene alkylation with propylene by zeolite catalyst can be illustrated by the following typical equations:

$$
\mathrm{S}_{V B}^{\mathrm{Bar} \mathrm{C}_{i}^{-}}=\frac{\text { quantity of benzene }(\mathrm{B}) \text { or propylene }\left(\mathrm{C}_{3}^{-}\right) \text {consumed for } \mathrm{PB} \text { obtained }}{\text { total quantity of reactant consumed in reaction }} \times 100
$$




\begin{tabular}{|c|c|c|c|c|c|c|}
\hline \multirow{2}{*}{ Parameter } & \multicolumn{6}{|c|}{ Test number } \\
\hline & $\mathrm{T}_{1}$ & $\mathrm{~T}_{2}$ & $\mathrm{~T}_{3}$ & $\mathrm{~T}_{4}$ & $T_{5}$ & $\mathrm{~T}_{6}$ \\
\hline $\mathrm{T},{ }^{\circ} \mathrm{C}$ & 250 & $250^{\circ}$ & 250 & $250^{\circ}$ & 250 & $250^{\circ}$ \\
\hline $\mathrm{P}$, atm. & 40 & 40 & 40 & 40 & 40 & 40 \\
\hline $\mathrm{B} / \mathrm{C}_{3}=$ & $7 / 1$ & $771^{-}$ & $7 / 1$ & 771 & $7 / 1$ & 771 \\
\hline Time, $\mathrm{h}$ & $39^{-}$ & 87 & 51 & 54 & 39 & $33^{-}$ \\
\hline WHSV, $\mathrm{h}^{-1}$ & 2.35 & 2.35 & 2.35 & 2.35 & 2.35 & $2.35^{\circ}$ \\
\hline $\mathrm{C}_{\mathbb{P B}}^{\max }, \%$ & 87.19 & 89.16 & 91.18 & 88.84 & 89.38 & 89.76 \\
\hline$\overline{\mathrm{C}}_{\mathrm{IPB}}, \%$ & 83.59 & 84.13 & 84.41 & 85.22 & 86.78 & 84.11 \\
\hline $\mathrm{S}_{\mathrm{IPB}}^{\mathrm{B}}, \%$ & 86.89 & 83.11 & 85.97 & 86.85 & 87.69 & 86.91 \\
\hline $\mathrm{S}_{\mathrm{IPB}}^{\mathrm{C}} \overline{\frac{\overline{3}}{\overline{3}}}, \%$ & 77.90 & 80.78 & 76.25 & 79.02 & 76.60 & 72,69 \\
\hline $\mathrm{S}_{\mathrm{dIPB}}^{\mathrm{B}}, \%$ & 1.59 & 4.26 & 3.10 & 4.47 & 2.4 & 3.05 \\
\hline $\mathrm{S}_{\mathrm{dIPB}}^{\mathrm{C}} \overline{\overline{3}}, \%$ & 2.85 & 8.29 & 5.51 & 8.43 & 4.67 & 5.10 \\
\hline
\end{tabular}

Table 2

VARIATION OF PROPYLBENZENES ZONCENTRATION AND HIS SELECTIVITY'S (MIDDLE VALUES PER TEST) IN BENZENE ALKYLATION OVER B-(AI)-HZSM-5

formation of secondary propenium ions

$$
\text { -alkylation }
$$

-transalkytion<smiles>CC(C)c1cccc(C(C)C)c1</smiles>

The formation of NPB during the alkylation catalyzed by zeolites has been reported as isomerization of IPB by intramolecular and by intermolecular transalkylation with benzene [44, 46]:

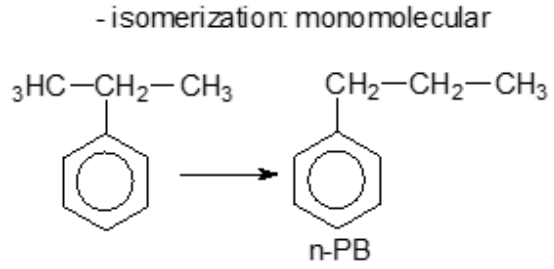

or bimolecular<smiles>CCCc1ccc(CCC)cc1</smiles> 
Acid - catalysed alkylation's reactions of benzene with propylene are commonly considered to take place via carbenium-ion type mechanism. Propylene is first protonated on Bronsted acid site forming the active carbocations (secondary propenium ions). By the electrophilic attack on secondary propenium ions on the benzene ring cumene (isopropylbenzene, IPB) is formed. Primary IPB can be dialkylated to 0-, p-, and m-DIPB.

Depending on reaction conditions and catalysts, the DIPB isomers can by transalkylate with benzene to cumene. NPB is a by-product that heavily affects the quality of cumene because of the difficulty to separate it from cumene. The active species (the isopropyl cations) can react with another propylene molecule producing $C_{6}$ species transformed through oligomerization, cracking, isomerization and alkylation into mainly propylene oligomers and alkylbenzenes.

\section{Conclusions}

B-(AI)-HZSM-5 catalyst presented good activities and selectivity's in reaction of benzene alkylation with a $\mathrm{C}_{3} / \mathrm{C}_{3}=$ technical fraction. IPB selectivity vs. of benzene and propylene consumed in reaction is upper $83 \mathrm{wt} . \%$, in all effectuated tests.

The n-PB, an undesirable by-product, is obtained in small quantity. The di-isopropylbenzenes (1,3-and 1,4-DIPB) are the important by-products because they are separated in the liquid product and by transalkylation reaction with benzene in excess producing a supplementary quantity of cumene. Benzene alkylation with propane -propylene mixture on the B-(Al)-HZSM-5catalyst has been demonstrated to be prospective routes for synthesis of isopropyl benzene.

The unique advantages of zeolites as replacements for conventional acids and bases catalysts will serve as driving force to continue the expansion of practical uses of zeolites.

\section{References}

1.BHAN, A., DELGASS, W.N., Catal. Rev. Sci. Eng., 50, No.1, 2008, p. 19. 2.Al-ZAHRANI, S.M., Chem. Eng., 6, No.1-2, 2008, p. 101.

3.CAEIRO, G. CARVALHO, R.H., WANG, X., LEMOS, M.A.N.D.A., LEMOS, F., GUISNET, M., RIBEIRO, F.R., J.Molec.Catal.A: Chemical, 255, No.12, 2006, p. 131.

4.FRICKE, R., KOSSLICK, H., LISCHKE, G., RICHTER, M., Chem. Rev., 100, No.6, 2000, p. 2303.

5.HAGEN, A., ROESSNER, F., Catal. Rev., 42, No. 4, 2000, p. 403. 6.BISCARDI, J.A., IGLESIA, E., Catal. Today, 31, 1996, p. 207; J. Phys. Chem., B102, 1998, p. 9284.

7.MERIAUDEAU, P., NACCACHE, C., Catal. Rev. Sci. Eng., 39, No. 1-2, 1997, p. 5.

8.GIANNETTO, G., MONQUE, R., GALIASSO, R., Catal. Rev. Sci. Eng., 36, No. 2, 1994, p. 271.

9.GUISNET, M., GNEP, N.S., ALARIO, F., Appl. Catal. A: General, 89, No.1, 1992, p. 1;

10.0NO, Y., Catal. Rev. Sci. Eng., 34, No. 3, 1992, p. 179.

11.SEDDON, D., Catal. Today, 6, 1990, p. 351.

12.ONO, Y., KITAGAWA, H., SENDODA, Y., J. Chem. Soc., Faraday Trans., 83, No.1, 1987, p. 2913.

13.SMIESKOVA, A., ROJASOVA, E., HUDEC, P., SABO, L., React. Kinet. Catal. Lett., 82, No.2, 2004, p. 227.

14.NICOLAIDES, C.P., SINCADU, N.P., SCURRELL, M.S., Catal. Today, 71, No.3-4, 2002, p. 429.

15.BISCARDI, J.A., IGLESIA, E., J. Catal., 182, No.1, 1999, p. 117. 16.BISCARDI, J.A., MEITZNER, G.D., IGLESIA, E., J. Catal., 179, No. 1, 1998, p. 192.

17.BERNDT, H., LIETZ, G., LÜCKE, B., VOLTER, R., Appl. Catal. A: General, 146, No. 2, 1996, p. 351.

18.ONO, Y., KANAE, K., J. Chem. Soc., Faraday Trans., 87, 1991, p. 663.
19.ASAFTEI, I. V., LUNGU, N. C., BIRSA, L. M., SARBU, L. G., SANDU, I. G., IGNAT, M., Rev. Chim. (Bucharest), 68, no.1, 2017, p. 116.

20.LI, Y., LIU, S., XIE, S., XU, L., Appl.Catal.A:General, 360, 2009, p. 8. 21.BILBA, N., IOFCEA, GH., ASAFTEI, I., PADURARIU, D. M., PAVEL, C. $C$., Proceedings of the $13^{\text {th }}$ Interantional Zeolite Conference, Montpellier, France, 8-13J uly, 2001, 24-P-30, Studies in surface Science and Catalysis, 135, 2001, p.2791.

22.ASAFTEI, I. V., BILBA, N., SANDU, I., Rev. Chim., (Bucharest), 64, no. 5, 2013, p. 509 .

23.ASAFTEI, I. V., BILBA, N., SANDU, I., Rev. Chim., (Bucharest), 64, no. 8, 2013, p. 836.

24.PEREGO. G., BELLUSSI, G., CORMO, C., TARA, M, BUIONOMO, F., ESPOSITO, $A_{\text {., }}$ in Proceedings of the $7^{\text {th }}$ International Zeolite Conference, MURAKAMI, Y., IIJIMA, A., WARDS, J., Eds., Elsevier, Amsterdam, 1986, Stud. Surf. Sci. Catal., 28, 1986, p.129.

25.ASAFTEI, I.V., LUNGU, N.C., SANDU, I., IGANT, M., Rev. Chim. (Bucharest), 68, no. 4, 2017, p.715.

26.ASAFTEI, I.V., EARAR, K., BIRSA, L.M.., SANDU, I.G., LUNGU, N.C.L., SANDU, I., Rev. Chim. (Bucharest), 66, no. 7, 2015, p. 963.

27.ASAFTEI, I.V., LUNGU, N.C., SANDU, I.G., SPAC, A.F., IGANT, M., Rev. Chim. (Bucharest). 69. no. 9, 2018, p. 2420.

28.ASAFTEI, I. V., BILBA, N., SANDU, I., Rev. Chim. (Bucharest), 65, no. 6, 2014, p. 697.

29.ASAFTEI, I. V., LUNGU, N. C., BIRSA, L. M., SARBU, L. G., IGNAT, M., SANDU, I. G., Rev. Chim. (Bucharest), 67, no. 8, 2016, p. 1523.

30.ASAFTEI, I.V., SANDU, I.G., BIRSA, L.M., MANEA, LILIANA, ROZEMARIE, EARAR, K., Rev. Chim. (Bucharest), 66, no. 3, 2015, p. 336.

31.ASAFTEI, I.V., LUNGU, N.C., SANDU, I., SPAC, A.F., IGANT, M., Rev. Chim. (Bucharest), 69, no. 4, 2018, p. 938.

32.MAFTEI, D., ASAFTEI, I. V., SANDU, I., MANEA, LILIANA, ROZEMARIE, BIRSA, L.M., EARAR, K., Rev. Chim. (Bucharest), 66, no. 5, 2015, p.673. 33.ASAFTEI, I. V., BILBA, N., SANDU, I., Rev. Chim. (Bucharest), 65, no. 4, 2014, p.431.

34.NAMBA, S., OHTA, H., KIM, J.-H., YASHIMA, T., in Proceedings International Congress of Catalysis, GUGYI, L., SOLYMOSI, F., TETENY, P., Eds., AkademiaiKiado, Budapest, 1986, p. 1685.

35.KLOTZ, M. R., US Patent 4269 813, 1981.

36.IVANOVA, I. I., ROMANOVSKY, B. V., TOPCHIEVA, K. V., MEGED, N. F., Neftekhimia, 27, 1988, p.460.

37.LIN, D. H., COUDURIER, G., VEDRINE, J. C., Stud. Surf. Sci. Catal., 49B, 1989, p.1431.

38.BORISOV, YU. V., IVANOVA, I. I., TOPCHIEVA, K. V., ROMANOVSKY, B., V., CHEMLEVA, T. A., MEGED, N. F., Vestn. Mosk. Univ., Ser. 2. Khim.,30, 1989, p.121.

39.PARICH, P. A., SUBRASHMANYAM, N., BHAT, Y. S., HALGERI, A. B., Appl. Catal., 90, 1992, p.1.

40.VENUTO, P. B., HAMILTON, L. A., LANDIS. P. S., WISE, J. J., J. Catal., 4, 1966, p.81.

41.VENUTO, P. B., HAMILTON, L. A., LANDIS. P. S., WISE, J. J., J. Catal., 5, 1966, p.484.

42.BECKER, K. A., KARGE, H. G, STREUBEL, W. D., J. Catal., 28, 1973, p.403.

43.PEREGO, C., AMARILLI, S., CARATI, A., FLEGO, C., PAZZUCONI, G., RIZZO, C., BELLUSSI, G., Microp. And Mesop. Materials, 27, 1999, p.345.

44.DWYER, F. G, LEWIS, P. J ., SCHNEIDER, F. M., Chem. Eng., 83, No.1, 1976, p. 90.

45.KAEDING, W. W., YOUNG, L. B., PRAPAS, A. G., Chemtech, 12, 1982, p. 556.

46. KAEDING, W. W., CHU, C., YOUNG, L. B., WEINSTEIN, B., BUTTER, S. A., J. Catal., 67, 1981, p.159.

47.CHEN, N. Y., GARWOOD, W. E., DWYER, F. G., Shape selective Catalysts in Industrial Applications, Marcel Dekker, New York and Basel, 1989, p.96.

48.BECK, J. S., DANDELAR, A. B., DEGNAN, T. F. JR., Zeolites for Cleaner Technologies, GUISNET, M., GILSON, J.-P., Eds., Catalytic science series, vol.3, Imperial College Press, London, 2002, p.223. 49.PRADHAN, A.R., RAO, B. S., J. Catal., 132, 1991, p.79. 
50.BELLUSSI, PAZZUCONI, G., PEREOGO, C., GIROTTI, G., TERZONI, G., J. Catal., 157, 1995, p.227.

51.WICHTERLOVA, B., CEJ KA, J , ZILKOVA, N., Microporous Materials, 6, 1996, p.405.

52.MEIMA, G. R., VAN DER AALST, M. J. M., SAMSON, M. S. U., GARCES, J. M., LEE, J. G., in Proceedings of the DGMK Conf. Catalysis on Solids Acids and Bases, Berlin, Germany, March, 14-15, 1996, WEITKAMP, J., LUCKE, B, Eds., 1996, p.125.

53.PEREGO, C., AMARILLI, S., BELLUSSI, G., CAPPELLAZO, O., GIROTTI, G., in Proceedings of the $12^{\text {th }}$ Int. Conf. Baltimore, USA, July 5-10, 1998, Materials Research Society, Warrendale, Pennsylvania, TREACY, M. M. J., MARCUS, B. K., BISCHER, M. E., HIGGINS, J. B., Eds., vol. I, 1999, p.575.

54.SMIRNOV, A. V., SHASKOV, A. A., IVANOVA, I. I., ROMANOVSKY, B. V., GABELICA, Z., in Proceedings of the $12^{\text {th }}$ Int. Conf. Baltimore, USA, July 5-10, 1998, Materials Research Society, Warrendale, Pennsylvania, TREACY, M. M. J., MARCUS, B. K., BISCHER, M. E., HIGGINS, J. B., Eds., vol. I, 1999, p.1207.

55.MAERZ, B. R., VENKAT, C. R., CHEN, S. S., MAZZONE, D. N., DEWITT, J., Petrochemical Review, Houston, March, 3-21, 1996.

56.CENG, J. C., DEGNAN, T. F., BECK, J. S., HUANG, Y. Y., KALYANARAMAN, M., KOWALSKI, J. A., LOEHR, C. A., MAZZONE, D. N., Stud. Surf. Sci. Catal., 105, 1998, p.56.
57.SMIRNOV, A. V., ROMANOVSKY, B. V., IVANOVA, I. I., DEROUANE, E. G., GABELICA, Z., in Zeolites and Related Microporous Materials; State of the Art, 1994, Studies in Surface science and Catalysis, Elsevier Science B. V., vol. 84, 1994, p. 1797.

58.BILBA, N., ASAFTEI, I., IOFCEA, GH., NAUM, N., in Proceedings of the $12^{\text {th }}$ Int. Zeolite Conf.; TREACY M..M..J ., MARCUS B.K., BISHER M.E., HIGGINS J.B., Eds.; Materials Research Society, Baltimore, USA, 1998, p. 2759.

59.ASAFTEI, I.V., LUNGU, N. C., SANDU, I., GSPAC, A. F., IGNAT, M., Rev. Chim. (Bucharest), 69, no.4, 2018, p.938.

60.BILBA, N., BILBA, D., VASILE A., CRUCEANU, M., ABABI, V., Brevet RO, R096844 (1988).

61.ARGAUER, R.J., LANDOLT, G.T., U.S. Patent US3702886 (1972).

62.OLSON, D.H., KOKOTAILO, G.T., LAWTON, S.L., MEIER, W.M., J. Phys. Chem., 85, 1981, p. 2238.

63.ASAFTEI, I.V., BILBA, N., SANDU, I., Rev. Chim. (Bucharest), 63, no. 10, 2012, p.1035

64.XIE, Y.C., TANG, Y.Q., Adv. Catal., 37, 1990, p.1.

65.CHEN, L.Z., FENG, Y.Q., Zeolites, 12, No.4, 1992, p. 347.

66.SULIKOWSKI, B., KLINOWSKI, J., Zeolite Synthesis, ACS Symposium Series, vol. 398, 1989,p. 393.

Manuscript received: 7.01 .2019 